\title{
8. COMPOSITION MAPS OF SURFACE SEDIMENTS OF THE EASTERN TROPICAL PACIFIC OCEAN ${ }^{1}$
}

\author{
Mitchell Lyle ${ }^{2}$
}

\section{INTRODUCTION}

The eastern tropical Pacific Ocean is a region having high primary productivity gradients associated with upwelling at coastal margins, equatorial divergence, and advection of nutrients by currents (see "Introduction" chapter, this volume). These gradients produce compositional changes in the surface sediments of the region. Understanding these modern sedimentation patterns is a vital step toward interpreting past environments and establishing how these differed from those in the modern world

The eastern equatorial Pacific region is topographically subdivided into the Guatemala Basin on the Cocos Plate, the Panama Basin (which straddles the Cocos and Nazca plates), and the Peru and BVauer basins on the Nazca Plate (Fig. 1). The East Pacific Rise separates these eastern Pacific Ocean basins from the Pacific Basin proper. Sill depths generally are deep, about $3 \mathrm{~km}$ in most cases, thus they are only partly separated from the main mass of Pacific Ocean deep water.

The primary latitudinal patterns of productivity and sedimentation are caused by zonal banding of the currents and by equatorial divergence. Nutrient-poor waters from the western Pacific Ocean are advected eastward into the eastern tropical Pacific region at about $5^{\circ} \mathrm{N}$, while the South Equatorial Current transports nutrient-rich waters from the margin of South America. Along the equator, productivity associated with the equatorial divergence provides another zonal pattern (Koblentz-Mishke et al., 1970). Superimposed upon this latitudinal pattern are (1) high productivity associated with coastal upwelling and (2) nutrient cycling near the continental margins.

This pattern is readily apparent in the depth to the brown-green color change in the uppermost seafloor sediments in the region (Fig. 2). Brown surface sediments are indicative of oxidizing sediment conditions, where $\mathrm{Fe}(\mathrm{III})$ is the stable oxidation state of Fe. As the flux of organic carbon to the sediments increases, the sediments become green at depth, where the $\mathrm{Fe}$ is reduced to $\mathrm{Fe}$ (II). The depth to this boundary is a good semiquantitative measure of both organic carbon flux and sedimentary redox intensity. In the eastern tropical Pacific Ocean, a shallow $\mathrm{Fe}(\mathrm{III}) / \mathrm{Fe}$ (II) boundary can be found along coastal margins and in the equatorial region. Around the Galapagos Islands, there is a complex structure to this pattern where island-induced upwelling occurs and where the equatorial undercurrent splits and occasionally surfaces (Pak and Zaneveld, 1973; Leetma, 1982). Sediments under the nutrient-poor North Equatorial Countercurrent form a tongue of brown sediment that extends eastward at $5^{\circ} \mathrm{N}$.

This brown-green color change is immediately discernible by macroscopic core description. Other patterns of sediment composition also exist, but can be studied only by chemical analysis of the sediments.

\footnotetext{
'Mayer, L., Pisias, N., Janecek, T., et al., 1992. Proc. ODP, Init. Repts., 138: College Station, TX (Ocean Drilling Program).

${ }^{2}$ Borehole Research Group, Lamont-Doherty Geological Observatory, Palisades, NY 10964, U.S.A.
}

\section{Sediment Composition}

METHODS

I analyzed a set of 250 core-top sediment samples using X-ray fluorescence (XRF) spectroscopy for 23 major and trace elements and also used a normative technique to calculate abundances of calcite and opal. In addition, I analyzed a subset of 150 samples sequentially by acidification and wet oxidation to determine organic carbon and for an independent measurement of calcite (Weliky et al., 1983). A comparison of the normative and LECO-based methods indicates that no systematic errors are associated with the normative method for determining calcite (Fig. 3).

\section{Sedimentation Rate Data}

I compiled average late Pleistocene-Holocene sedimentation rates for the eastern tropical Pacific Ocean on the basis of various dating techniques that included oxygen isotope stratigraphy, uraniumseries isotopic measurements, radiocarbon dating, and depth to ash layers of known age (Fig. 4). I used carbonate contents of the samples to estimate their bulk density (equation from Murray, 1987) and combined this information with estimated sedimentation rates at each sample location to create maps of elemental mass accumulation rates (MAR) for the region. These MARs are not highly accurate because of errors associated with the different estimates needed to construct them. Nevertheless, they should provide a first-order representation of sediment fluxes in the region.

\section{TERRIGENOUS DEPOSITION}

The pattem of terrigenous deposition in the region is best illustrated by the contour map of aluminum MAR presented in Figure 5. Not surprisingly, high deposition rates of terrigenous debris generally occur within $500 \mathrm{~km}$ of the coast and of the Galapagos Platform. A diagonal pattern of accumulation that cuts across the map from $12^{\circ} \mathrm{S}$ to a westward-extending tongue at $5^{\circ} \mathrm{N}$, where the Intertropical Convergence normally is located, may indicate dust transport from South America via the southeast tradewinds.

In addition, a tongue of high aluminum flux extends southward in the Guatemala Basin on the eastern side of the East Pacific Rise. This tongue may be associated with counterclockwise deep flow within the basin. An annual current meter record from $200 \mathrm{~m}$ above the seafloor (sbf) at MANOP Site M, on the East Pacific Rise at $8^{\circ} 45^{\prime} \mathrm{N}$ (Fig. 6), shows that the near-bottom flow along the rise crest at $9^{\circ} \mathrm{N}$ is to the south-southwest, and that tongue of high aluminum extends outward in this direction. The distribution of the ratio of $\mathrm{Fe}: \mathrm{Al}$ in the surface sediments (not shown here) also suggests that hydrothermal plume material injected into deep waters moves northeastward into the Guatemala Basin from the triple junction of the East Pacific Rise and the Galapagos Spreading Center. If these two flows are connected, average water flow must be counterclockwise around the basin. 


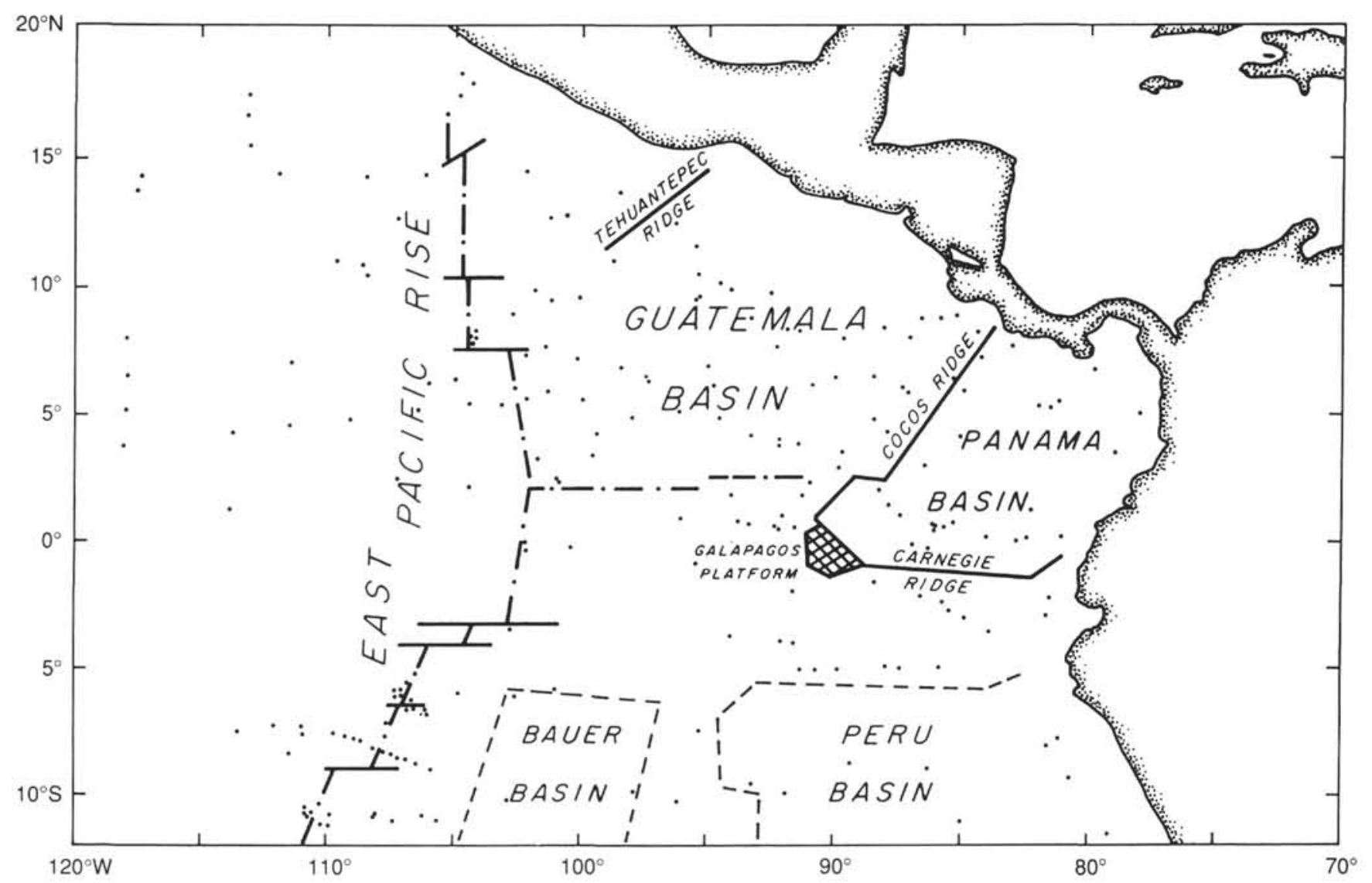

Figure 1. Basins and defining ridges of the eastern tropical Pacific Ocean.

\section{CARBONATE DEPOSITION AND CARBONATE COMPENSATION DEPTH FOR THE EASTERN PACIFIC BASINS}

The distribution of surface-sediment calcite contents (on an opalfree basis) for the eastern tropical Pacific Ocean is presented in Figure 7. This distribution of calcite is almost the inverse of the aluminum MARs (Fig. 5). Near the coast of the Americas, terrigenous deposition dilutes the calcite and is partly responsible for its pattern.

Depth-dependent carbonate dissolution is also a major factor reducing the calcite content, because the eastern tropical Pacific region is bounded by subduction zones along continental margins. The oldest, deepest ocean crust thus is nearest the continents, while the carbonate lysocline throughout the region is shallow. In addition, organic carbon fluxes to the sediments are highest near the continents. Acid and $\mathrm{CO}_{2}$ generated by oxidation of organic matter also helps to reduce calcite contents (Emerson and Bender, 1980).

West of the East Pacific Rise, a region of high carbonate sediments fans out to the north and to the south. Bottom waters of the Pacific Basin proper are less corrosive to carbonate than those of the more restricted basins to the east, probably because organic carbon fluxes into the deep waters of the eastern basins are much higher and the added $\mathrm{CO}_{2}$ and organic acids make them more corrosive to calcite.

This basinal difference is well illustrated in plots of carbonate MAR vs. water depth for the different eastern Pacific basins (Fig. 8). In the Pacific Basin, carbonate MARs are still significantly above zero, even at $4500 \mathrm{~m}$ below sea level. In the Peru Basin, essentially no calcite collects below $4100 \mathrm{~m}$. In the Guatemala and Panama basins, the calcite compensation depth (CCD) occurs at approximately 3700 and
$3200 \mathrm{~m}$, respectively. Tracking the history of the CCD in the different basins is one approach for studying integrated productivity in these basins, provided that each basin retains distinctive deep waters and each has similar deep-water influxes.

Carbonate MARs of the surface sediments (Fig. 9) have a somewhat different pattern than those in the calcite concentration map. The greatest accumulation of carbonate occurs on the equator, with the highest rates around the Galapagos Islands. This pattern follows the high topography of the East Pacific Rise southward, away from the equator. High carbonate MARs along the equator suggest that productivity is an important part of the flux and burial of calcite in the eastern tropical Pacific region.

\section{OPAL DEPOSITIONAL PATTERNS}

The highest normative opal contents in the eastern Pacific Ocean (on a calcite-free basis; Fig. 10) parallel the equator (and also lie somewhat south of it). This pattern is similar to that observed by Leinen (1986) and, in part, is a dilutional pattern, because terrigenous deposition contributes significantly to the noncarbonate fraction of sediments to the north of the equator.

When opal concentration data are converted to MARs, the pattern of opal flux becomes more symmetrical about the equator, but is still skewed slightly to the south (Fig. 11). This offset may be a result of nutrient advection from the east in the South Equatorial Current and an asymmetry in advection of upwelled nutrients southward from the equator. The highest opal MARs occur in the Galapagos upwelling area and extend along the equator. High opal fluxes also are found near coastal areas, especially in the Costa Rica Dome area near $10^{\circ} \mathrm{N}$, 


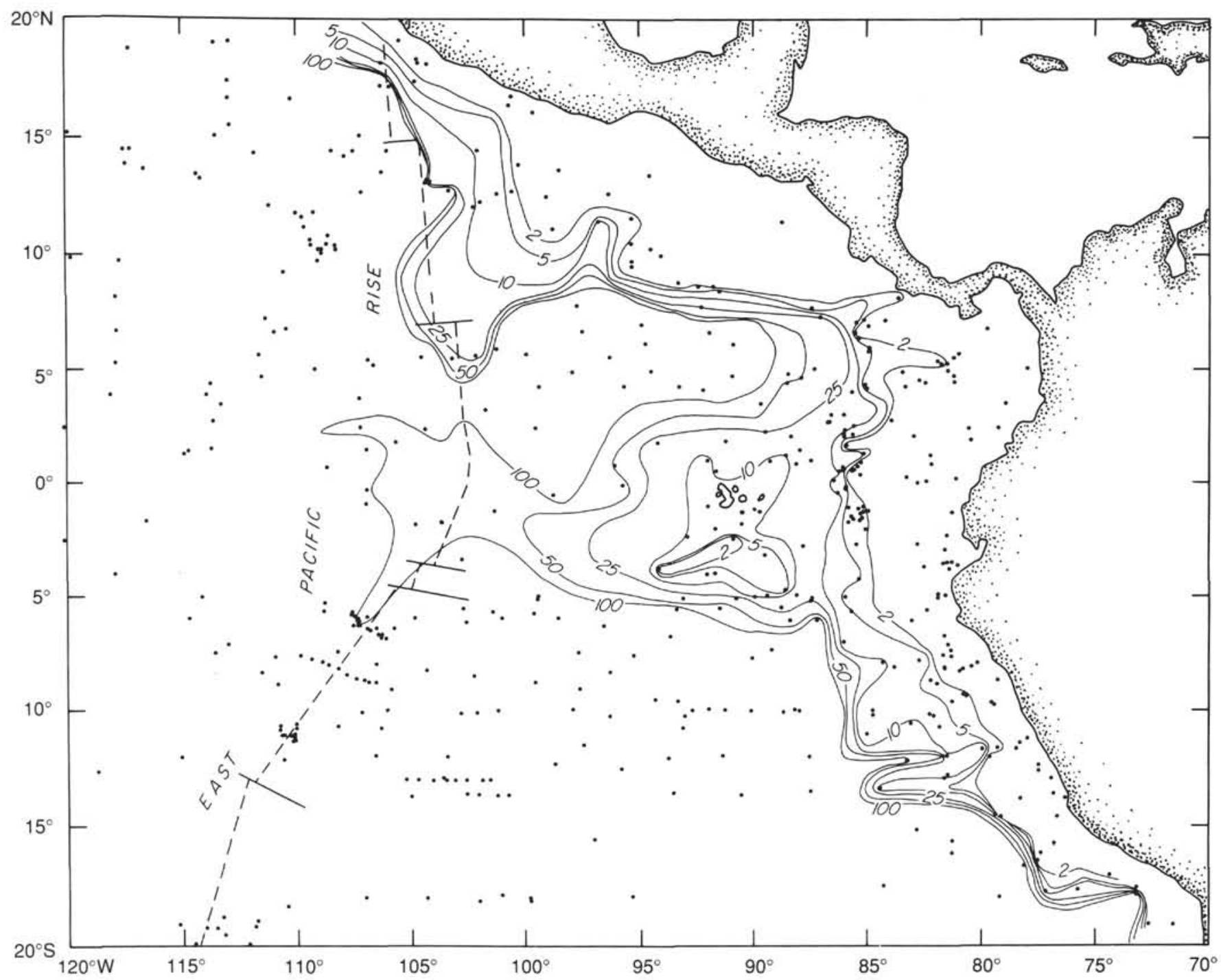

Figure 2. Thickness (cm) of the brown Fe(III)-bearing surface sediment layer in the eastern tropical Pacific Ocean (from Lyle, 1983). Positions of cores used to compile this map are shown as dots. A thin brown surface layer is an indication of high organic carbon flux to the sediments.

$90^{\circ} \mathrm{W}$ and along the coast of Peru. As few or no data can be found on the margin proper, the coastal MARs may be lower than what one might expect on the basis of primary productivity information.

\section{ORGANIC CARBON PERCENTAGES AND FLUXES}

The organic carbon content in the sediments is high near the coastal areas and decreases offshore. Even with the poor sample coverage near the continents, the "margin effect" is apparent (Fig. 12), Organic carbon contents within a few hundred kilometers of the coast are in the range of $1.5 \%$ to $2 \%$. Organic carbon contents rapidly decrease in the offshore direction, to less than $0.5 \%$. Even the low organic carbon contents are accurate and reproducible, because I was able to replicate a measurement of $0.18 \%$ organic carbon repeatedly on a carbonate-rich sediment standard with $3 \%$ relative precision $( \pm 0.005 \%)$ during these sample runs.

Only along the equator do pelagic sedimentary organic carbon contents exceed $0.6 \%$, and only rarely did values of organic carbon exceed $1 \%$. The highest organic carbon contents along the equator are beneath the upwelling zone just to the west of the Galapagos Islands. This equatorial high organic carbon region is separated from the coastal organic carbon high to the north by a region of low organic carbon content in sediments beneath the North Equatorial Countercurrent. The highest organic carbon values in the northern "coastal" region are associated with the Costa Rica Dome at about $10^{\circ} \mathrm{N}, 90^{\circ} \mathrm{W}$, but another high can be found at approximately $10^{\circ} \mathrm{N}, 100^{\circ} \mathrm{W}$ that may be associated with the typical northern-winter "Tehuantepecker" and "Papagayo" jet-induced upwelling events (Clarke, 1988; Legeckis, 1988). In part, high organic carbon contents in the Panama Basin also may be the result of this type of upwelling. The high organic carbon contents along the coast of Peru appear in these data to some extent, but the extremely organic-carbon-rich sediments along this margin were not sampled for this study. Some sediments in this region have $20 \%$ organic carbon by weight (Suess, von Huene, et al., 1988).

Conversion to MARs sharpens the features discernible in the map of organic carbon content (Fig. 13). High organic carbon deposition is associated with equatorial divergence, and the burial of organic carbon decreases dramatically, even along the equator, away from the continental margins. The highest values along the margin (at about $5^{\circ}$ ) are artifacts of the limited coastal data set. More complete information from these margins most probably would expand this region southward along the coast of Peru. 


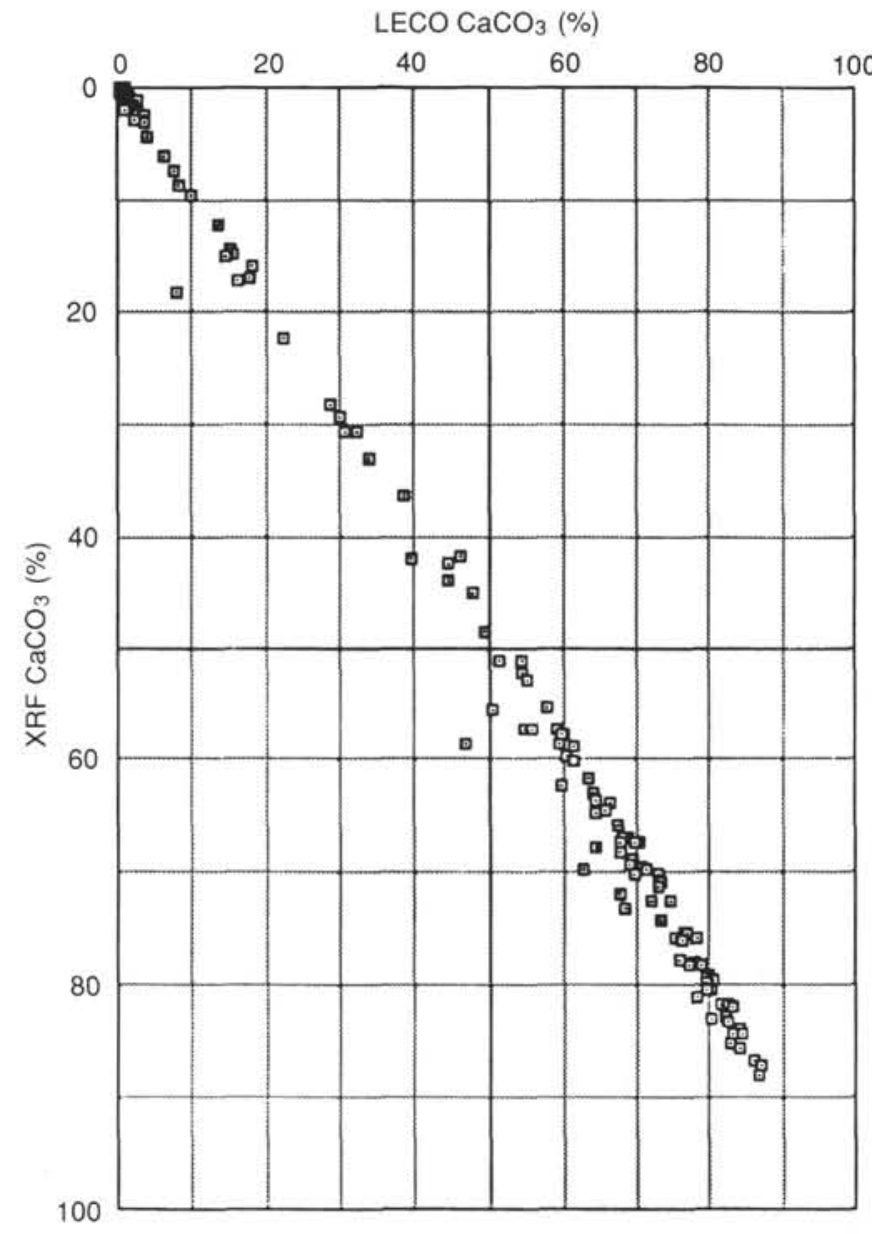

Figure 3. Comparison of calcite determined normatively from XRF analysis with the same samples analyzed using Weliky et al.'s method (1983). No systematic differences were found in the measurements.

\section{COMPARISON OF SEDIMENT PATTERNS TO PRODUCTIVITY}

A detailed comparison of primary productivity with organic carbon or opal burial is difficult because of the high degree of seasonality for primary productivity in the eastern equatorial Pacific (Fig. 14). Seasonal variation in productivity can exceed a factor of 5 , and interannual effects also are large. Both of these levels of variability make high-resolution maps of productivity difficult to compile. World maps of productivity, such as those of Koblentz-Mishke et al. (1970) or Berger et al. (1987), have insufficient resolution to compare easily with surface sediment data. Synoptic productivity information, such as estimates from satellite monitoring of ocean color, will be neces- sary to improve our understanding of the relationships between production and burial of biogenic material. Nevertheless, regional patterns suggest that deposition of opal, calcite, and organic carbon is affected strongly by productivity. High fluxes of all three components are associated with high productivity and reflect the complex oceanographic region of the Eastern Equatorial Pacific Ocean.

\section{REFERENCES}

Berger, W. H., Fisher, K., Lai, C., and Wi, G., 1987. Ocean Productivity and Organic Carbon Flux. Part I. Overview and Maps of Primary Production and Export Production: San Diego (University of California), SI0 ref. 97-30.

Clarke, A. J., 1988. Inertial wind path and sea surface temperature patterns near the Gulf of Tehuantepec and Gulf of Papagayo. J. Geophys. Res., 93:15491-15501.

Emerson, S. E., and Bender, M., 1981. Carbon fluxes at the sediment/water interface of the deep sea: calcium carbonate preservation. J. Mar. Res. $39: 139-162$

Koblentz-Mishke, O. I., Volkovinsky, V. V., and Katanova, J. G., 1970. Plankton primary production of the world ocean. In Wooster, W. (Ed.), Scientific Exploration of the South Pacific National Academy of Sciences: Washington D.C. (South Pacific Natl. Acad. Sci.), 183-193.

Leetma, A., 1982. Observations of near-equatorial flows in the eastern Pacific. J. Mar. Res., 40 (Supp):357-370.

Legeckis, R., 1988. Upwelling off the Gulfs of Panama and Papagayo in the tropical Pacific during March 1985. J. Geophys. Res., 93:15485-15489.

Leinen, M., Scwienk, D., Heath, G. R., Dauphin, J. P., Thiede, J., Kolia, J., and Biscaye, P., 1986. Distribution of quartz and biogenic silica in recent deep-sea sediments. Geology, 14:199-203.

Love, C. M. (Ed.), 1972. EASTROPAC Atlas 6: Washington (U.S. Govt. Printing Office), Dept. of Commerce Circ. 330.

Love, C. M., and Allen, R. M. (Eds.), 1975. EASTROPACAtlas 10: Washington (U.S. Govt. Printing Office), Dept. of Commerce Circ. 330.

Lyle, M., 1983. The brown-green color change: a marker of the Fe(III)Fe(II) redox boundary. Limnol. Oceanogr., 28:1026-1033.

Lyle, M., Owen, R. M., and Leinen, M., 1986. History of hydrothermal sedimentation at the East Pacific Rise, $19^{\circ}$ S. In Leinen, M., Rea, D. K., et al., Init. Repts. DSDP, 92: Washington (U.S. Govt. Printing Office), 585597.

Murray, D. W., 1987. Spatial and temporal variations in sediment accumulation in the central tropical Pacific. [Ph.D. dissert.] Oregon State University, Corvallis.

Pak, H., and Zaneveld, J.R.V., 1973. The Cromwell Current on the east side of the Galapagos Islands. J. Geophys. Res., 78:7845-7859.

Suess, E., von Huene, R., et al., 1988. Introduction, scientific objectives, and principal results, Leg 112, Peru Continental Margin. Proc. ODP, Init. Repts., 112: College Station, TX (Ocean Drilling Program), 5-25.

Weliky, K., Suess, E., Ungerer, C. A., and Fisher, K., 1983. Determination of organic carbon and calcite in sedimentary samples: a new approach. Limnol. Oceanogr., 28:1252-1259.

\section{Ms 138A-108}




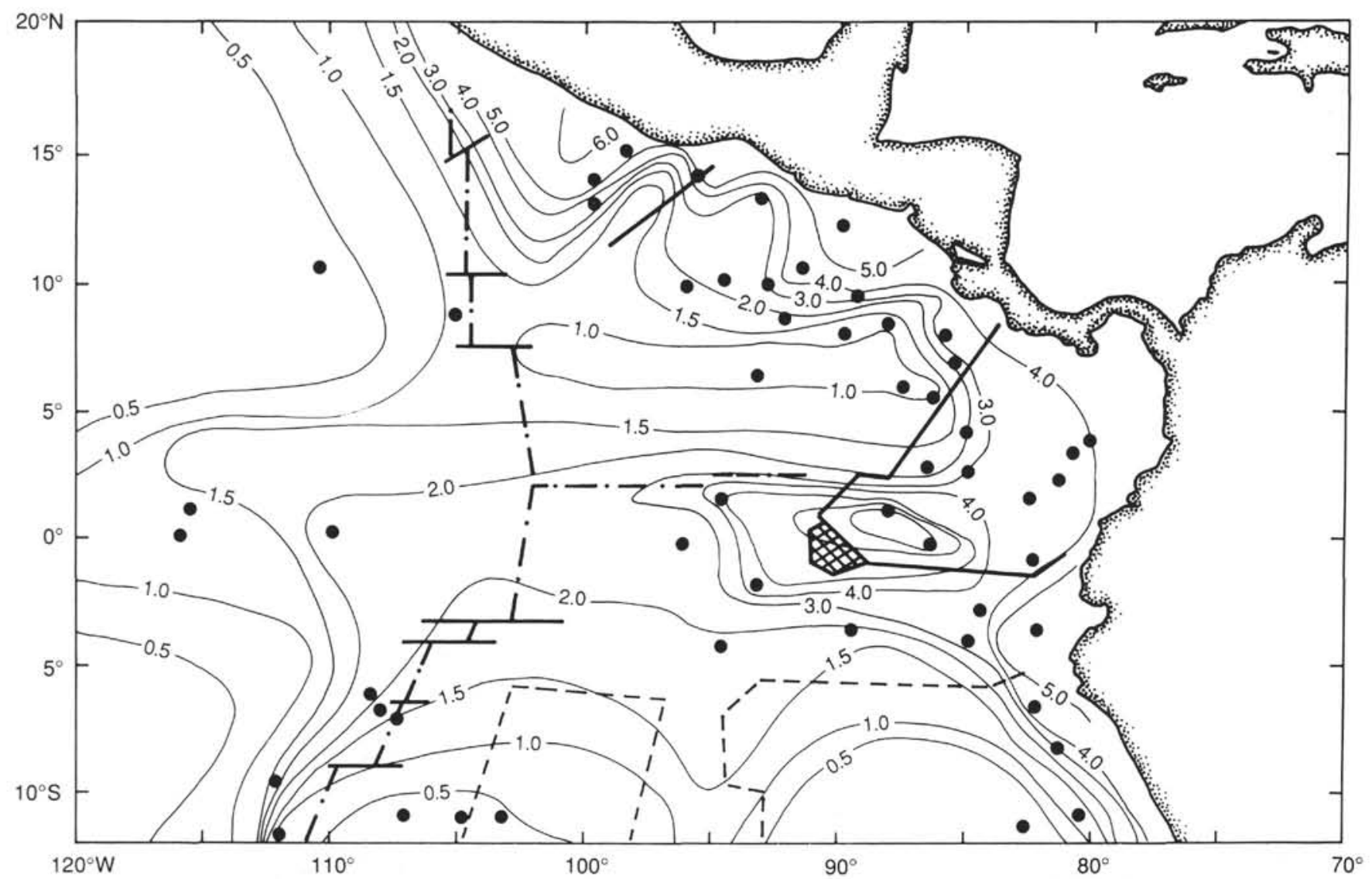

Figure 4. Map of late Pleistocene-Holocene sedimentation rates for the eastern tropical Pacific Ocean, compiled from oxygen isotope stratigraphy, depth to ash layers of known age, U-series dating, and radiocarbon dating. Sedimentation-rate contour units are $\mathrm{cm} / \mathrm{k}$.y. Positions of cores used to compile this map are shown as dots. See Figure 1 for key to basinal features. 


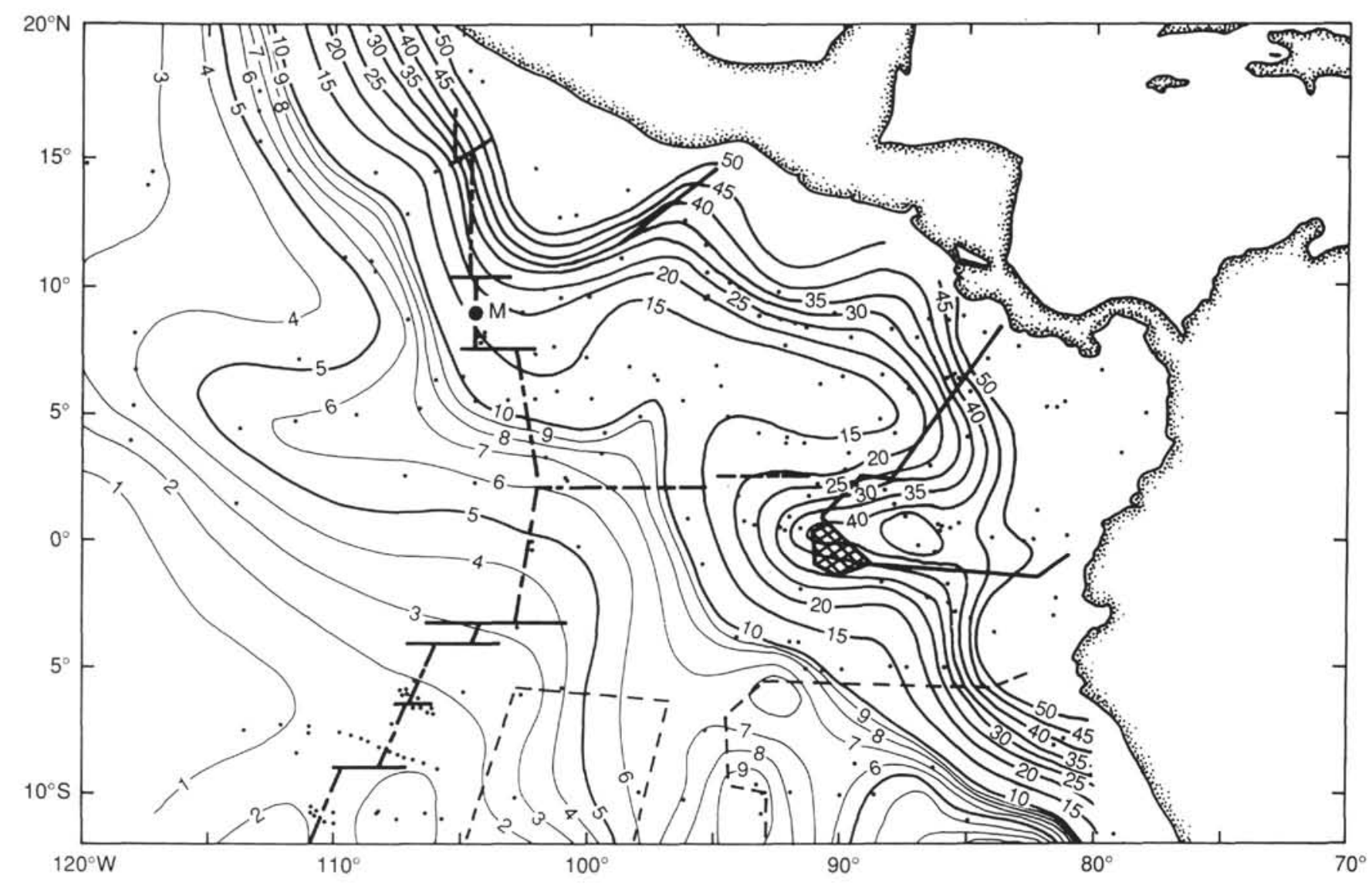

Figure 5. Aluminum MAR pattern in the eastern tropical Pacific Ocean. Coastal areas are marked by high deposition and a lobe that extends from the southeast at $12^{\circ} \mathrm{S}$ to the west at $5^{\circ} \mathrm{N}$ may mark southeast tradewinds. The lobe that extends south from Mexico along the East Pacific Rise marks bottom-water flow. Contour units are $\mathrm{mg} / \mathrm{cm}^{2} / \mathrm{k}$.y. Positions of cores used to compile the map are shown as dots. Location of MANOP Site M is shown. See Figure 1 for key to basinal features. 

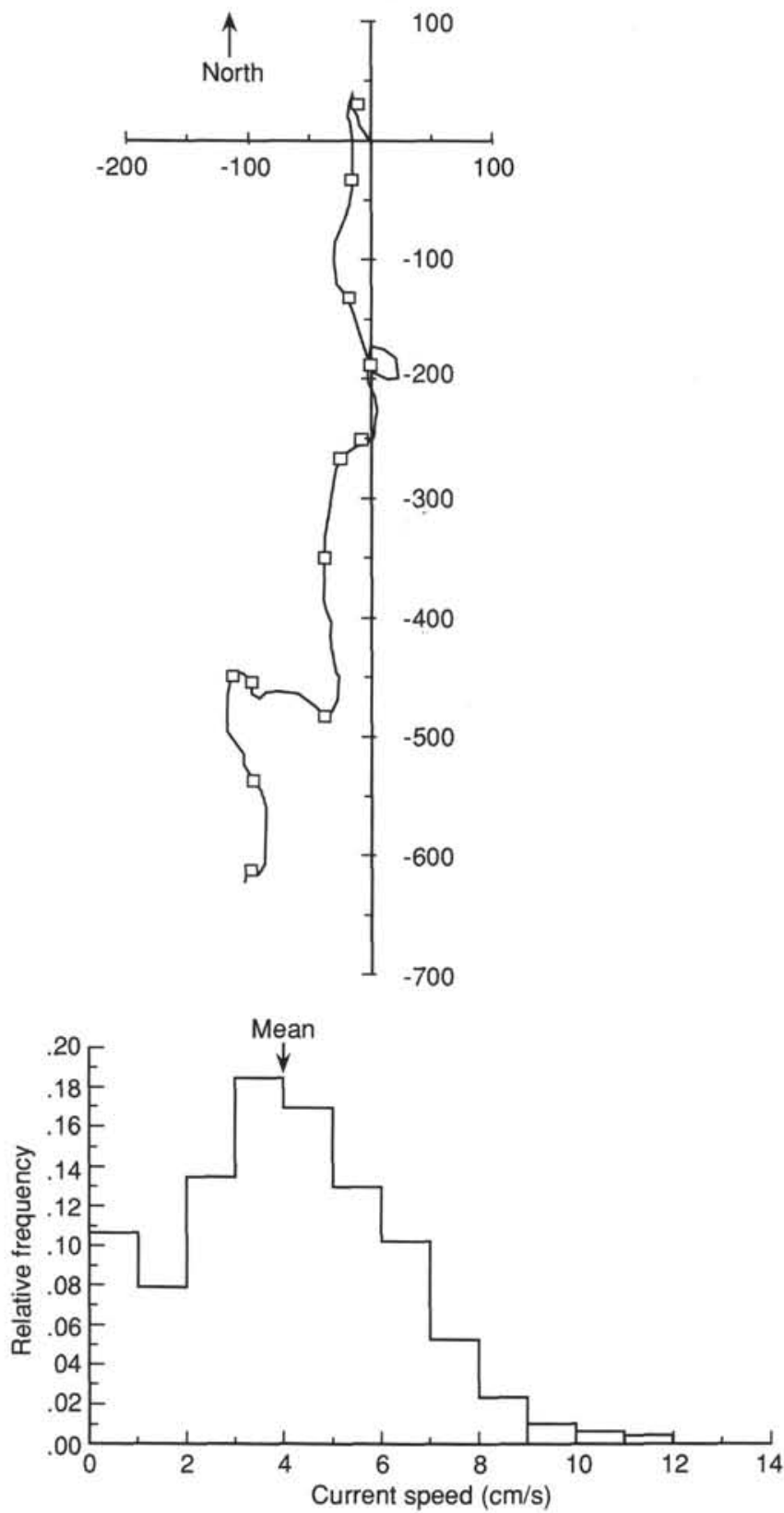

Figure 6. Summed vector diagram of bottom currents on the East Pacific Rise $\left(8^{\circ} 45^{\prime} \mathrm{N}, 104^{\circ} \mathrm{W}\right.$, from Lyle et al., 1986). Average direction for the year is south-southwest. See Figure 1 for key to basinal features. 


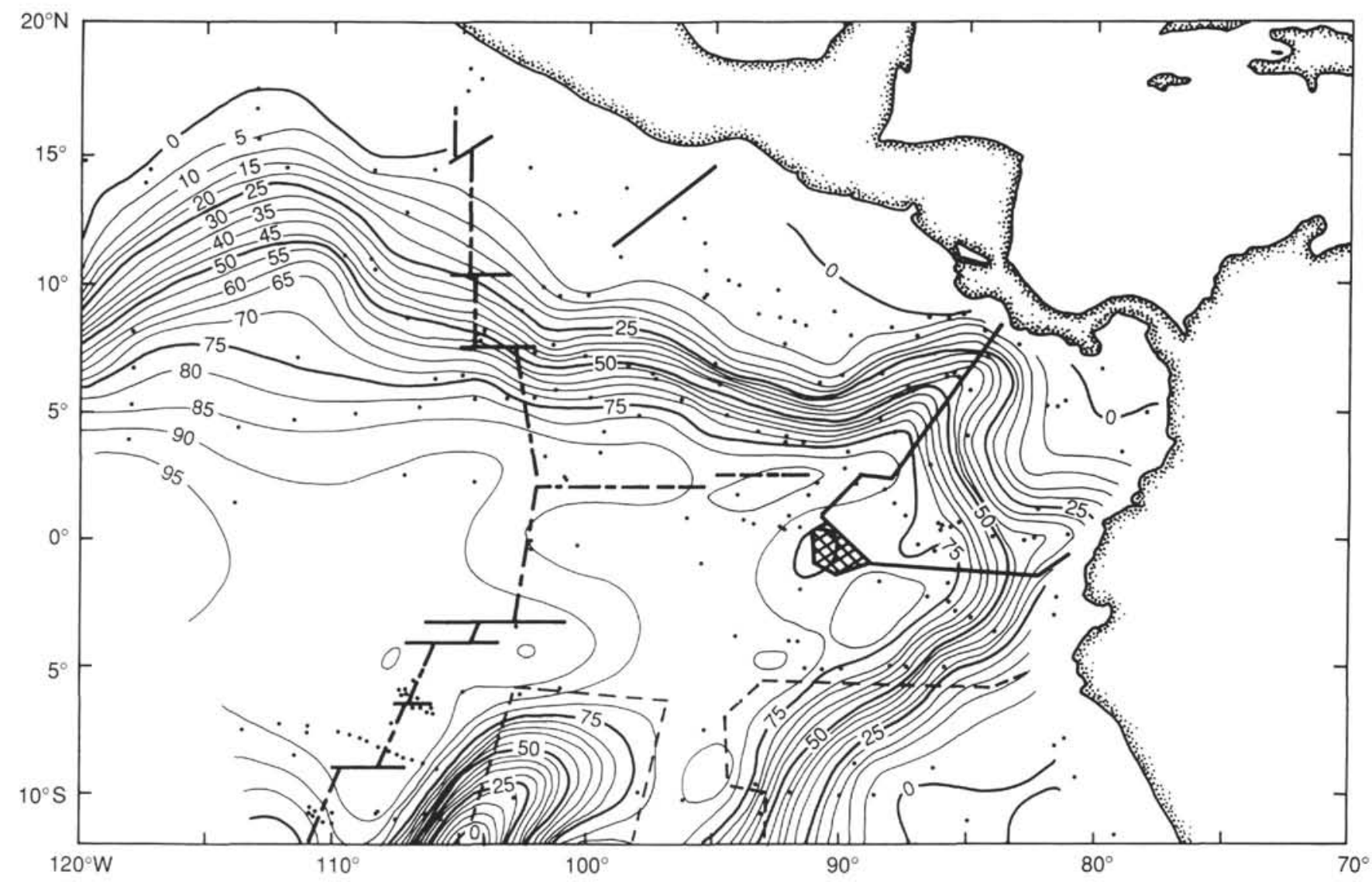

Figure 7. Contents of opal-free calcite in eastern Pacific sediments. Contour intervals are 5\%. 

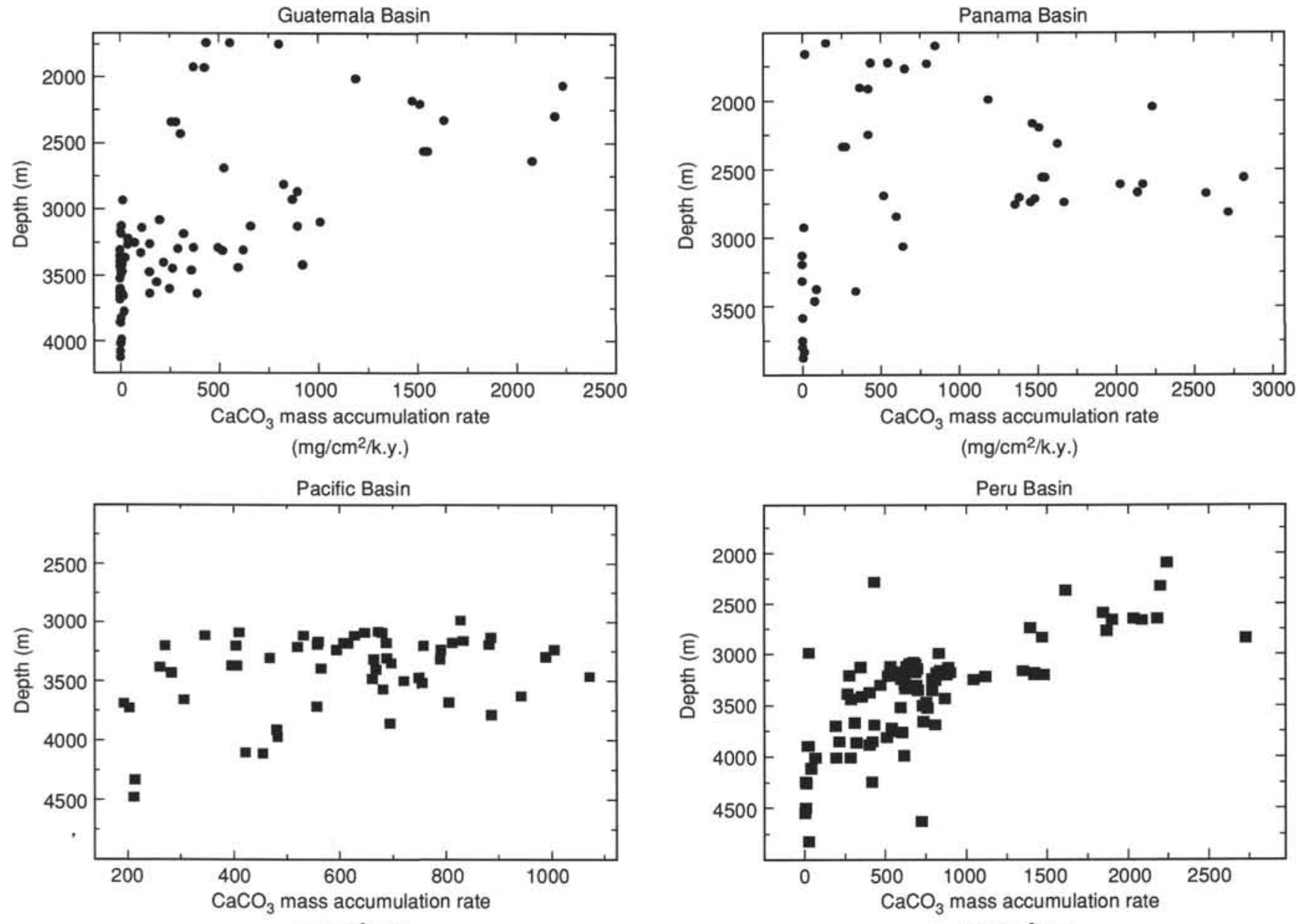

$\left(\mathrm{mg} / \mathrm{cm}^{2} / \mathrm{k} . \mathrm{y}\right.$.)

$\left(\mathrm{mg} / \mathrm{cm}^{2} / \mathrm{k} . \mathrm{y}\right.$.)

Figure 8. $\mathrm{CaCO}_{3}$ MARs vs. depth in water column for the different Eastern Pacific basins. Note that the Panama Basin has the shallowest CCD, followed by the Guatemala and Peru basins. 


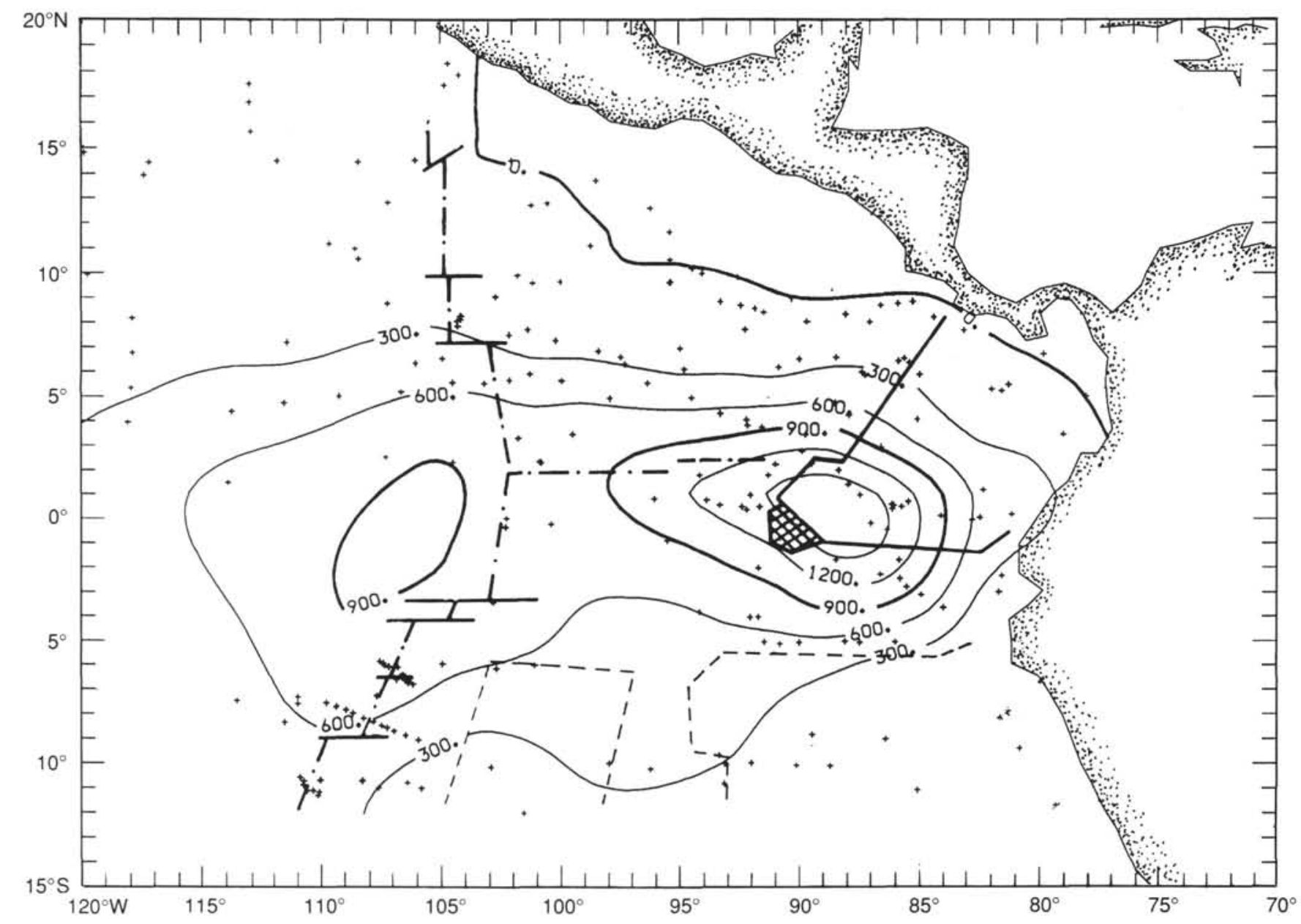

Figure 9. Calcite MARs in the eastern tropical Pacific Ocean. Note how highest calcite burial is associated with high topography at the equator. Contour units are $\mathrm{mg} / \mathrm{cm}^{2} / \mathrm{k}$.y. Dots indicate location of cores used to determine contours. See Figure 1 for key to basinal features. 


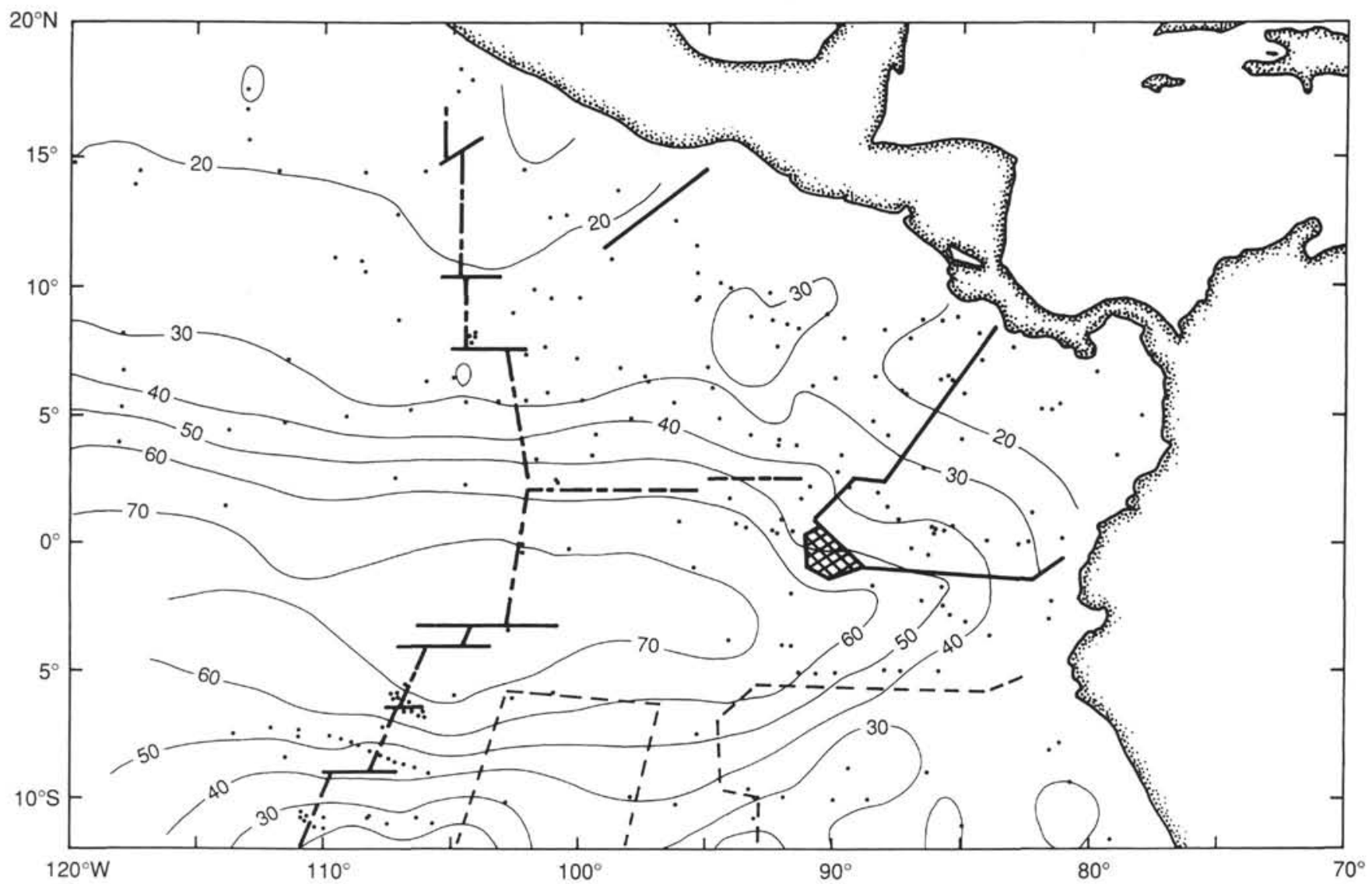

Figure 10. Percentage of calcite-free opal contents in eastern Pacific sediments. The highest opal contents are found south of the equator, partly because of dilution from the north. Dots indicate location of cores used to determine contours. 


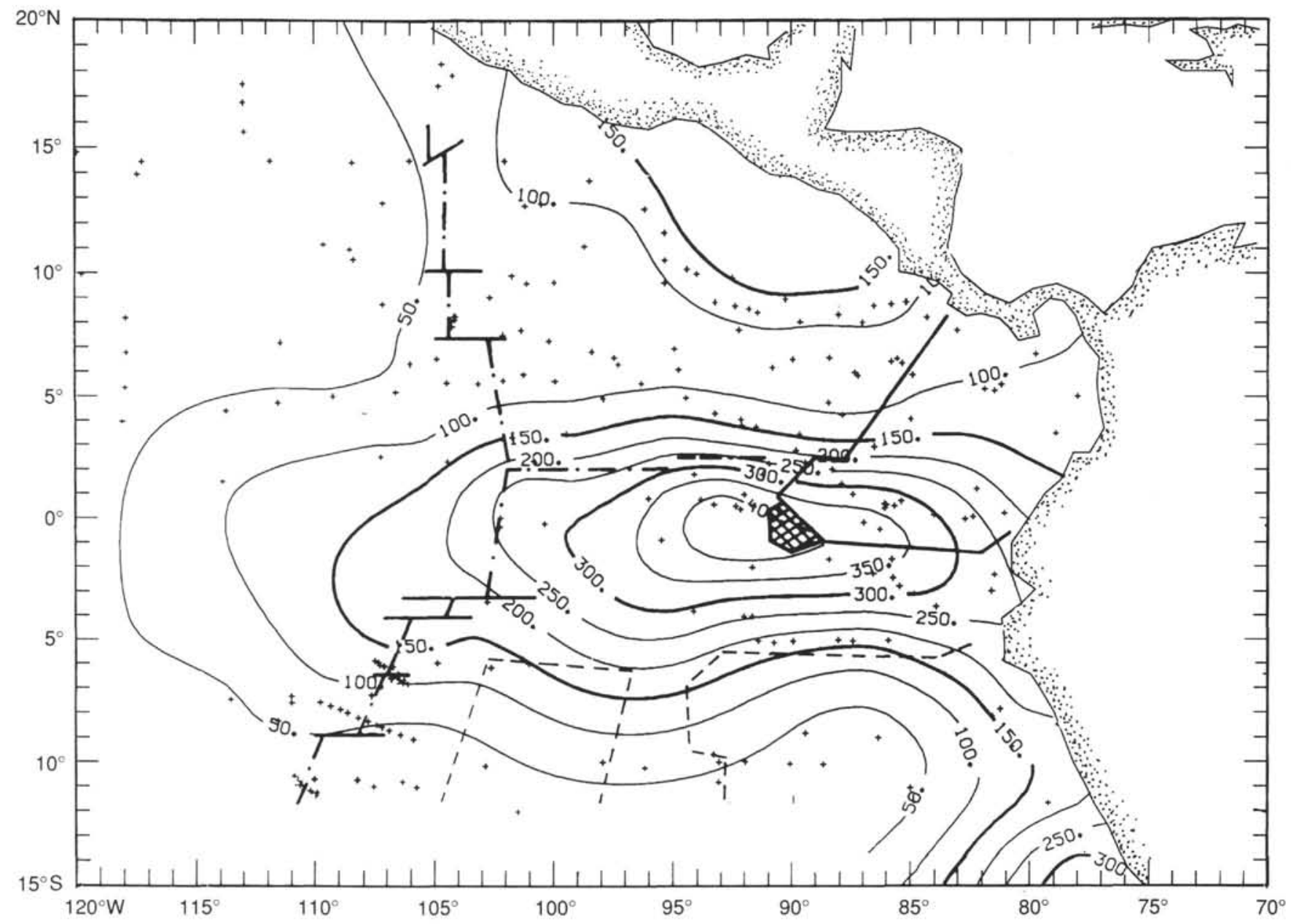

Figure 11. Opal MARs are more symmetrical about the equator, but still shift slightly to the south. Contour units are $\mathrm{mg} / \mathrm{cm}^{2} / \mathrm{k}$.y. Dots indicate location of cores used to determine contours. See Figure 1 for key to basinal features. 


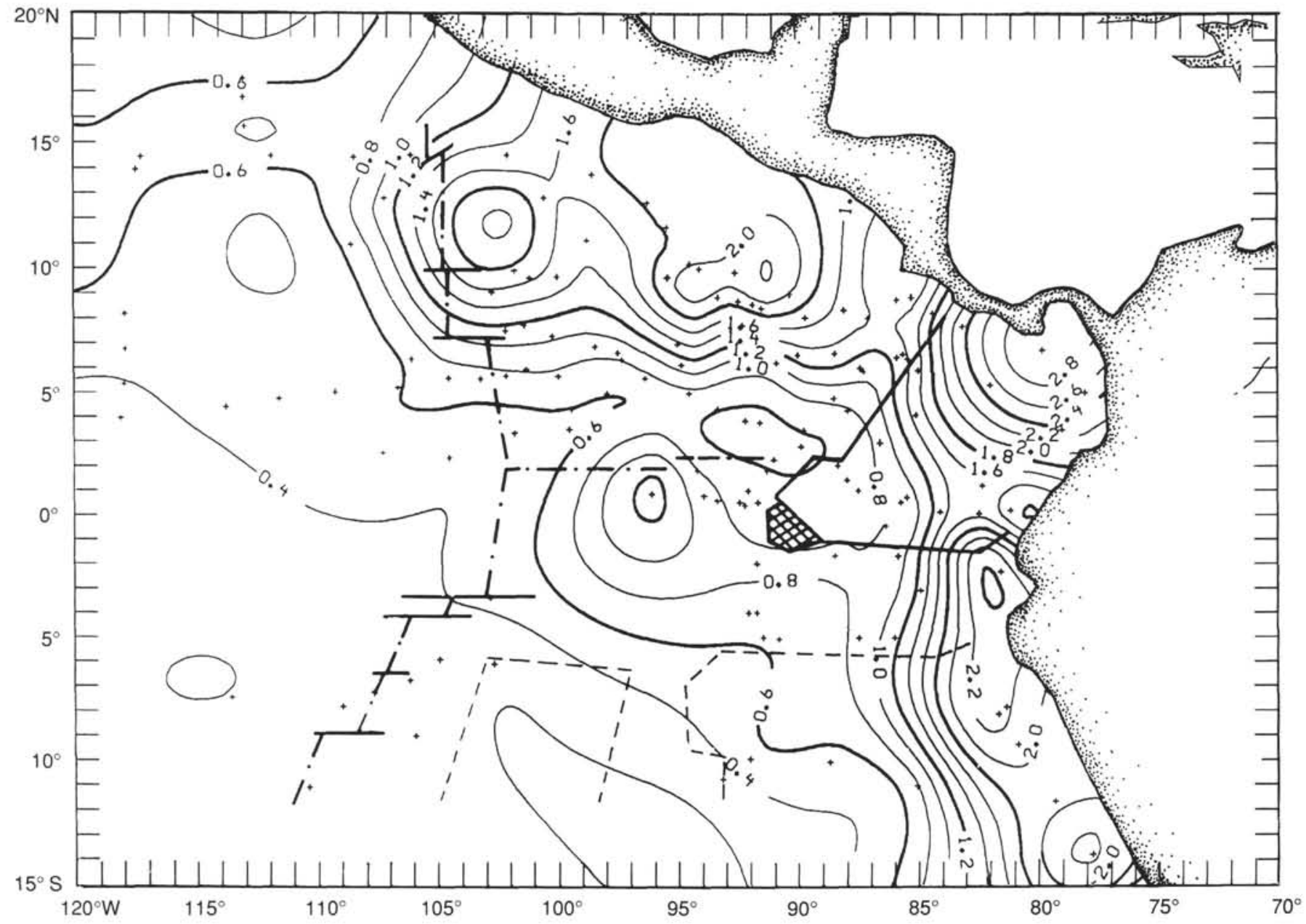

Figure 12. Percentage of organic carbon contents of eastern Pacific Ocean surface sediments. High organic carbon is found near the coast and along the equator. Contour units are $\mathrm{mg} / \mathrm{cm}^{2} / \mathrm{k} . \mathrm{y}$. Dots indicate location of cores used to determine contours. See Figure 1 for key to basinal features. 


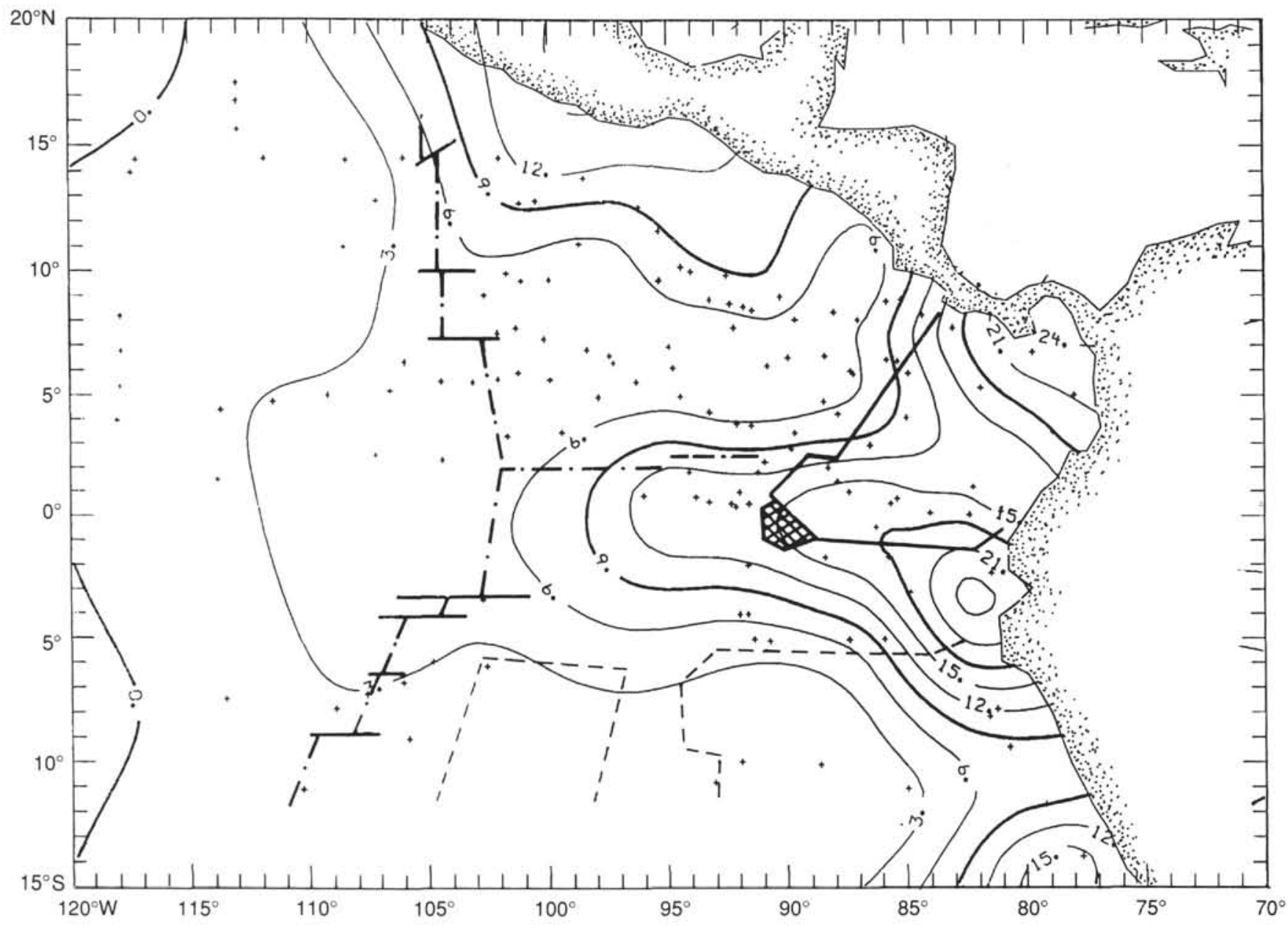

Figure 13. Organic carbon MARs from the eastern tropical Pacific. The pattern of deposition along the equator becomes more clear, and low organic carbon MARs associated with the North Equatorial Countercurrent at $5^{\circ} \mathrm{N}$ stand out. Contour units are $\mathrm{mg} / \mathrm{cm}^{2} / \mathrm{k}$.y. Dots indicate location of cores used to determine contours. See Figure 1 for key to basinal features. 

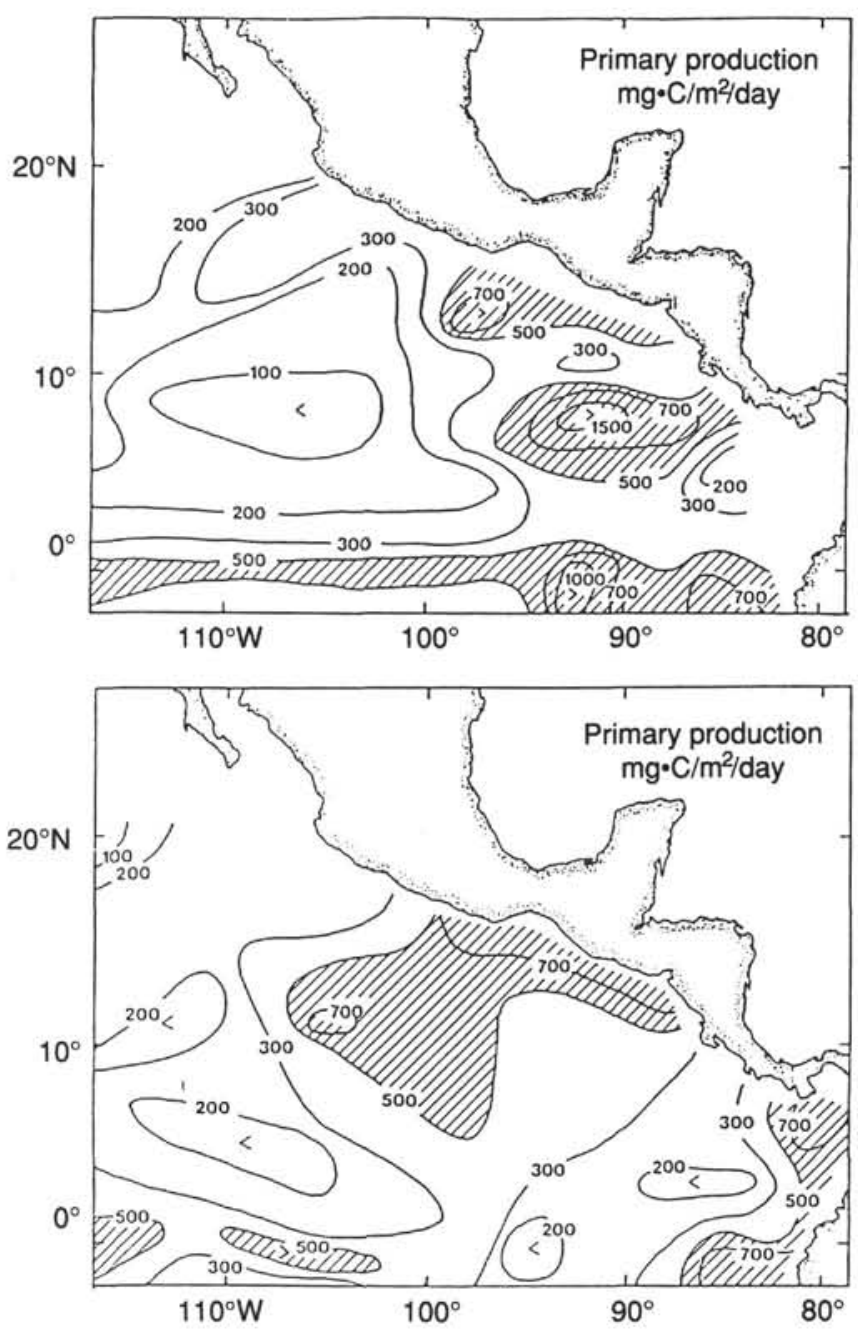

Figure 14. Primary production in the eastern tropical Pacific for AugustSeptember (top) and February-March (bottom). Note how productivity can change by a factor of 5 or more seasonally (from Love, 1972; Love and Allen, 1972). 